\title{
Stress/inflammation and pai-1 as stellar processes in the aging and associated pathologies
}

\author{
${ }^{1}$ Hematologic MD PHD, Logroño, La Rioja, Spain \\ ${ }^{2}$ Tedec-Meji Farma, SA. Alcalá de Henares, Madrid, Spain \\ ${ }^{3}$ Pharmaceutical Act, Ministry of Health, Regional Government, Logroño, La Rioja Spain \\ ${ }^{4}$ Aragón Health Service, Zaragoza, Spain \\ ${ }^{5}$ Sciences Faculty, Navarra University, Spain \\ ${ }^{6}$ Pharmacy Faculty, Valencia University, Spain
}

Lasierra-Cirujeda ${ }^{1 *}$, Coronel P², Aza Pascual-Salcedo MJ ${ }^{3}$, Gimeno M$^{2}$, Aza Pascual-Salcedo MM4, Lasierra-Ibañez $\mathrm{A}^{5}$ and Lasala-Aza C

Decades ago Hans Hugo Bruno Selye expressed the concept of stress as a pathophysiological syndrome generated by various endogenous / exogenous harmful agents and named it as the "General Adaptation Syndrome". This concept implicitly involves a complex process of damage and specific or non-specific defence of the organism that accompanies us throughout life, especially in the aging process and the diseases associated, whose symptoms are independent of the nature of the harmful agent, representing a response to the damage as such [1-3].

The development of the individual after their conception, development and later decline phase is accompanied of processes due to stress alarms of small intensity [4-7] and it constantly produces homeostatic adaptations $[8,9]$ through sub lethal exposures of stressors (Hormesis) [10]. At the experimental level, tensions of greater intensity, cause progressive changes in the anatomical structure and function of the different organs, as well as vascular infarcts by intravascular coagulation in the hypothalamic-pituitary-adrenal-renal (HPA) axis [11]. This brings a marked increase in PAI-1 expression in induced stress [12-16] or in the presence of any chronic/acute phase inducer, which would explain the frequency of cardiovascular-thrombotic complications in aging [17].

Aging is recognized as a substrate of risk for the accumulation of multiple diseases of chronic evolution, producers of biomarkers indicative of the alteration of different physiological mechanisms. A myriad of theories or hypotheses have been exposed to explain the aging process [18], being the theories of free radicals and genomics the most accepted ones and related as a response to stress [19-23]. Nowadays aging is summarized as a process generated by a synergistic action between two or more causes producing a progressive damage to molecules, cells, organs and systems.

Aging begins with the organic and functional decline of the organism and leads to a progressive decrease of the main cellular and extracellular antioxidant: glutathione (GSH), giving rise to the complex mechanism of oxidative stress (OS) that plays a great role in the development of aging and associated diseases.

Both chronic stress and inflammation play a key role in the onset and progression of the different chronic pathologies that frequently accompany the development of aging [24]. It is well documented that the pathophysiology of chronic disease that underlies the process of aging, involves secretion by adipose tissue (especially abdominal type, of pro-inflammatory markers (adipokines) setting a pathophysiological crossroads that increases the risk of morbidity/mortality. Likewise, in the development of aging there is a higher concentration of proinflammatory cytokines in the cerebral compartment as well as peripheral [25-27].

It is well documented how the prevalence of obesity in the more developed Western countries is increasing in all age groups, even in the old age one. This is correlated with stress through the activation of the HPA axis, favouring the accumulation of fat and exerting a mild chronic and inflammatory stressing action with release of substances from adipose tissue (adipokines, cytokines, hormones ...) that alter the metabolic balance leading to the most frequent metabolic pathology that accompanies aging [28]. This originates a common denominator of complex mechanisms that acting enchained and constitutes a pathophysiological crossroad at the systemic level as well and in the brain compartment, acquiring the ubiquitous PAI-1 (plasminogen activator inhibitor-1) gene acquiring a stellar role $[29,30]$.

The PAI-1 is a strategic gene whose activity in both physiology and pathology represents a challenge for the student. It is well known the importance of PAI-1 as an inhibitor of plasminogen activators, t-PA and u-PA, regulating the systemic fibrinolytic mechanism in the field of thromboembolic disease, and at the level of the brain compartment regulating $\beta$-amiloidolysis [31]. Besides, it is of great interest the pathophysiological function developed by PAI-1 in aging and the multiple pathology associated: obesity, metabolic syndrome, type 2 diabetes, neurodegenerative pathology (mainly in Alzheimer's Disease and Parkinson's Disease), cancer (PAI-1 can be involved in the onset, progression and metastasis of some neoplasia), cardiovascular processes and thromboembolic complications. These clinical entities clearly show increased levels of PAI-1, leading some researchers to suggest the use of PAI-1 inhibitors with therapeutic purposes in those risk processes where reduction to physiological levels could be of interest [32-39].

Correspondence to: J Lasierra-Cirujeda, MD, PHD Gran Vía, n $73,1^{\circ} \mathrm{B}$ Logroño. (La Rioja) Spain, E-mail: hematol@telefonica.net

Received: February 02, 2018; Accepted: February 23, 2018; Published: February 26,2018 


\section{This abstract is a preview of the work}

Stress / Inflammation / PAI-1 in the pathophysiological crossroad of aging and associated diseases.

Lasierra-Cirujeda J, Coronel P, Aza Pascual-Salcedo MJ, Gimeno M, Aza Pascual Salcedo MM, Lasierra -Ibañez A, Lasala-Aza C. Under preparation.

\section{References}

1. Selye H (1936) Syndrome produced by diverse nocuous agents. Nature 138: 32.

2. Selye H (1946) The general adaptation syndrome and the diseases of adaptation. J Clin Endocrinol Metab 6: 117-230. [Crossref]

3. Selye H (1950) Stress and the general adaptation syndrome. Br Med J 1: 1383-1392. [Crossref]

4. Karrow NA (2006) Activation of the hypothalamic-pituitary-adrenal axis and autonomic nervous system during inflammation and altered programming of neuroendocrineimmune axis during fetal and neonatal development: lessons learned the model inflammagen, lipopolysaccharide. Brain Behav Immun 20: 144-158. [Crossref]

5. Calabrese EJ, Bachmann KA, Bailer AJ, Bolger PM, Borak J, et al. (2007) Biological stress response terminology: Integrating the concepts of adaptive response and preconditioning stress within a hormetic dose-response framework. Toxicol Appl Tharmacol 222: 122-128. [Crossref]

6. Rattan SI (2008) Hormesis in aging. Ageing Res Rev 7: 63-78. [Crossref]

7. Rattan SI (2014) Aging is not a disease: implications for intervention. Aging Dis 5: 196-202. [Crossref]

8. Bernard C (1957) An introduction to the study of experimental medicine. 1865. Originally published in 1860; first English translation by Henry Copley Greene, published by Macmillan \& Co., Ltd. 1927; Dover edition.

9. Cannon WB (1933) Physiological regulation of normal states: some tentative postulates concerning biological homeostatics. In: Pettit A, editor. A Charles Richet: ses amis, ses collã"gues, ses Ã®lÃ"ves (in French) Paris: Les editions MÃ@dicales.

10. Davies KJ (2016) Adaptive homeostasis. Mol Aspects Med 49: 1-7. [Crossref]

11. Lasierra J (1968) Contribuci $\tilde{A}^{3} n$ a la distribuci $\tilde{A}^{3} n$ vascular y topogrÃ $\tilde{f i c a}_{\text {fica }}$ neurosecretora en la superficie de contacto hipofisaria, as $\tilde{A}$ como a la vascularizaci $\tilde{A}^{3} \mathrm{n}$ visceral concomitante en conexi $\tilde{A}^{3} n$ con los estados de alarma experimental. Anales de Anatom $\tilde{A} a$ 17: 485-536.

12. Colucci M, PÃ iramo JA, Collen D (1985) Generation in plasma of a fast-acting inhibitor of plasminogen activator in response to endotoxin stimulation. $J$ Clin Invest 75: 818-824.

13. Pralong G, Calandra T, Glauser MP, Schellekens J, Verhoef J, et al. (1989) Plasminogen activator inhibitor 1: a new prognostic marker in septic shock. Thromb Haemost 61: 459-462. [Crossref]

14. Quax PH, van den Hoogen CM, Verheijen JH, Padro T, Zeheb R, et al. (1990) Endotoxin induction of plasminogen activator and plasminogen activator inhibitor type $1 \mathrm{mRNA}$ in rat tissue in vivo. J Biol Chem 265: 15560-15563. [Crossref]

15. Yamamoto K, Loskutoff DJ (1996) Fibrin deposition in tissue from endotoxin-treated mice correlates with decreases in the expression of urokinase-type but not tissue-type plasminogen activator. $J$ Clin Invest 97: 2440-2451.

16. Yamamoto K, Takeshita K, Shimokawa T, Yi H, Isobe K, et al. (2002) Plasminogen activator inhibitor-1 is a major stress-regulated gene: Implications for stress-induced thrombosis in aged individuals. PNAS 99: 890-895. [Crossref]
17. Yamamoto K, Takeshita K, Kojima T, Takamatsu J, Saito H, et al. (2005) Aging and plasminogen activator inhibitor-1 (PAI-1) regulation: implication in the pathogenesis of thrombotic disorder in the elderly. Cardiovascular Research 66: 276-285. [Crossref]

18. Medvedev ZA (1990) An attempt at a rational classification of theories of ageing. Biol Rev Camb Philos Soc 65: 375-398. [Crossref]

19. Harman D (1956) Aging: a theory based on free radical and radiation chemistry. $J$ Gerontol 11: 298-300. [Crossref]

20. Knight JA (2000) The biochemistry of aging. Adv Clin Chem 35: 1-62. [Crossref]

21. Viña J, Borrás C, Miquel J (2007) Theories of ageing. IUBMB Life 59: 249-254. [Crossref]

22. Liochev SI (2013) Reactive oxygen species and the free radical theory of aging. Free Radic Biol Med 60: 1-4. [Crossref]

23. Moskalev AA, Aliper AM, Smit-McBride Z, Buzdin A, Zhavoronkov A (2014) Genetics and epigenetics of aging and longevity. Cell Cycle 13: 1063-1077. [Crossref]

24. Lavretsky H, Newhouse PA (2012) Stress, inflammation, and aging. Am J Geriatr Psychiatry 20: 729-733. [Crossref]

25. Bruunsgaard H, Pedersen M, Pedersen BK (2001) Aging and proinflammatory cytokines. Curr Opin Hematol 8: 131-136. [Crossref]

26. Alvarez-Rodríguez L, López-Hoyos M, Muñoz-Cacho P, Martínez-Taboada VM (2012) Aging is associated with circulating cytokine dysregulation. Cell Immunol 273: 124-132. [Crossref]

27. Michaud M, Balardy L, Moulis G, Gaudin C, Peyrot C, et al. (2013) Proinflammatory cytokines, aging, and age-related diseases. J Am Med Dir Assoc 14: 877-882. [Crossref]

28. Kyrou I, Chrousos GP, Tsigos C (2006) Stress, visceral obesity, and metabolic complications. Ann N Y Acad Sci 1083: 77-110. [Crossref]

29. Antuna-Puente B, Feve B, Fellahi S, Bastard JP (2008) Adipokines: the missing link between insulin resistance and obesity. Diabetes Metab 34: 2-11. [Crossref]

30. Uchida Y, Takeshita K, Yamamoto K, Kikuchi R, Nakayama T, et al. (2012) Stress augments insulin resistance and prothrombotic state: role of visceral adipose-derived monocyte chemoattractant protein-1. Diabetes 61: 1552-1561. [Crossref]

31. Lasierra-Cirujeda J, Coronel P, Aza M, Gimeno M (2013) Beta-amyloidolysis and glutathione in Alzheimer's disease. J Blood Med 4: 31-38. [Crossref]

32. Higgins PJ (2006) The TGF-Î²/upstream stimulatory factor-regulated PAI-1 gene: Potential involvement and a therapeutic target in alzheimerâ's disease. $J$ Biomed Biotechnol 2006; 15792.

33. Lasierra-Cirujeda J, Coronel Granado P (2006) Study on the safety, efficacy, and efficiency of sulodexide compared with acenocumarol in secondary prophylaxis in patients with deep venous thrombosis. Angiology 57: 53-56. [Crossref]

34. Lasierra-Cirujeda J, Coronel P, Aza M, Gimeno M (2010) Use of sulodexide in patients with peripheral vascular disease. J Blood Med 1: 105-115. [Crossref]

35. Tjmlund-Wolf AT, Brogren H, Lo IH (2012) Plasminogen activator inhibitor-1 and thrombotic cerebrovascular diseases. Stroke 43: 2833-2839.

36. Eren M, Boe AE, Kliachko EA, Vaughan DE (2014) Role of Plasminogen Activator Inhibitor-1 in senescence and Aging. Semin Thromb Hemost 2014; 40 (06): 645-651. [Crossref]

37. Baluta MM, Vintila MM (2015) PAI-1 Inhibition - Another Therapeutic Option for Cardiovascular Protection. Maedica (Buchar) 10: 147-152. [Crossref]

38. Lasierra-Cirujeda J, Aza MJ, Aza MM (2016) Sulodexide and Alzheimers disease: A preliminary prospective study. World J Cardiovascular Disease 6: 54-71. [Crossref]

39. Lasierra-Cirujeda J, Aza Pascual-Salcedo MJ, Lasierra IbaÃez A, Lasala Aza C, Aza Pascual-Salcedo MM (2016) Aging: thromboembolic disease, metabolic syndrome, type 2 diabetes mellitus, and alzheimerâ's disease. J Biosciences Med 4: 1-20.

Copyright: (C2018 Lasierra-Cirujeda J. This is an open-access article distributed under the terms of the Creative Commons Attribution License, which permits unrestricted use, distribution, and reproduction in any medium, provided the original author and source are credited. 